\title{
РАЗВИТИЕ ИДЕИ НРАВСТВЕННОГО ВОСПИТАНИЯ В ПЕДАГОГИЧЕСКОМ НАСЛЕДИИ С.А. РАЧИНСКОГО
}

\section{DEVELOPMENT OF THE IDEA OF MORAL EDUCATION IN THE PEDAGOGICAL HERITAGE OF S. A. RACHINSKY}

\section{A. Maistrenko}

Summary: The purpose of the study is to determine the features and direction of the idea of moral education in the pedagogical heritage of the people's educator Sergei Alexandrovich Rachinsky. The article shows the foundations of the moral education of the famous teacher. Much attention is paid to the understanding of what should constitute the content of education in school, priority disciplines are marked. The thoughts of S.A. Rachinsky regarding the role and function of the teacher in primary education are considered, which are not limited only to the presentation of the subject material. The paper also describes the practical experience of S.A. Rachinsky in the construction and management of schools. Methods: analysis, synthesis, generalization, contributed to the interpretation and integration of information on the topic under study contextual analysis, taking into account the signs of the context of the idea being formed; historical and typological helped to identify the general, most characteristic features and sides of the phenomenon under study in order to organize it. The study revealed the enormous influence of the Orthodox Church and general Christian values on the idea of moral education in S.A. Rachinsky's pedagogy. Moral education was aimed at the formation of a whole, healthy personality in the child, possessing Christian and universal qualities.

Keywords: S.A. Rachinsky, moral education, folk school, church.

\author{
Майстренко Алексей Игоревич \\ Аспирант, Красноярский государственный \\ педагогический университет имени В.П. Астафьева \\ aleksei.maistrenko@mail.ru
}

Аннотация: Цель исследования - определить особенности и направленность идеи нравственного воспитания в педагогическом наследии народного просветителя Сергея Александровича Рачинского. В статье показаны основания нравственного воспитания знаменитого педагога. Большое внимание уделено пониманию того, что должно составлять содержание образования В школе, отмечены приоритетные дисциплины. Рассмотрены мысли С.А. Рачинского относительно роли и функции учителя в начальном образовании, которые не ограничиваются только лишь изложением предметного материала. В работе также описывается практический опыт С.А. Рачинского в строительстве и руководстве школами. Методы: анализ, синтез, обобщение, способствовали интерпретации и объединению информации по исследуемой теме контекстуальный анализ, учитывающий признаки контекста формировавшейся идеи; историко-типологический помогал выявить общие, наиболее характерные признаки и стороны исследуемого явления с целью его упорядочения. В результате исследования выявлено огромное влияние православной церкви и общехристианских ценностей на идею нравственного воспитания в педагогике С.А. Рачинского. Нравственное воспитание было направленно на формирование в ребёнке цельной, здоровой личности, обладающей христианскими и общечеловеческими качествами.

Ключевые слова: С.А. Рачинский, нравственное воспитание, народная школа, церковь.

ретическими положениями умственного, нравственного и духовного образования и воспитания в церковноприходской школе, разработанными К.П. Победоносцевым.

Интересно, что он относился к задаче духовного и нравственного совершенствования максимально лично. Это заметно из письма к К.П. Победоносцеву (1880), в котором он писал о том, что «нужно завоевать себе право читать Евангелие детям, не краснея» [7, с. 65]. На протяжении своей жизни он организовал более двадцати начальных школ, четыре из которых содержал сам.

Будучи единомышленником своего современника С.А. Рачинский считал, что основой для общественного единства выступает церковь, которая должна иметь тесное сотрудничество со школой. Он разрабатывал цель воспитания с точки зрения православной традиции, а именно - воцерковление души человека, её можно достичь лишь посредством воцерковления школы. Цен- 
тральной фигурой в образовательном учреждении помимо учителя является ещё и законоучитель-священник, они в равной степени важны. Законоучитель-священник в школе выполняет не только роль учителя, но и пастыря. Церковная школа воспитывает добрый характер, благочестие, добродетели и христианскую жизнь.

С.А. Рачинский пристальное внимание концентрировал на содержании образования в сельской школе и, особенно, изучении русской грамоты и арифметики. Родители видели, что их дети становятся грамотными, и оставляли их для обучения в школе не на 4 года, но на 5-6 лет. С.А. Рачинский полагал, "как только родители поверят в школу, убедятся, что она сообщает прочную практически полезную грамотность, церковную и гражданскую, навык к быстрому и точному счету, что она обучает детей молитве и страху Божию, школа смело может углубить свой учебный курс и по времени, и по содержанию" [4, с. 67]. Первостепенными в школе являются церковное пение, подлинное благочестие, интерес к категориям веры и духа. Обучающиеся с неподдельным желанием читают и переписывают молитвы, стихотворения, отрывки из книг, имеющих духовно-нравственное содержание.

Изучение церковнославянского языка, богослужение, церковное пение, иконопись повышают интерес школьников к церкви. Рачинский говорил, что, всякое образовательное заведение в качестве покровителя должна иметь православную церковь. По его убеждению, в России два источника нравственного воспитания личности церковь и книга.

Публицист и философ XIX в. В.В. Розанов относился к школе Рачинского как к "рассаднику школ и сельских учителей". Его школа сохранилась и до наших дней. Он проявил себя ещё и как строитель, впервые в России построив школу с интернатом, а, выражаясь его же словами: "сельскую школу с общежитием", но, интересно заметить, что П.Ф. Каптерев не поддерживал идею существования подобных школ: "план Рачинского во многом русским школам неприменим" [2, с. 607].

Школа народного учителя, профессора Сергея Александровича Рачинского, как считали его современники и почитатели, давала подросткам целостное миропонимание, основанное на традиционных народных духовнонравственных идеалах православия. Школа опиралась на народную и православную педагогику, что приносило свои позитивные результаты в нравственном воспитании подростков и детей, которые становились тружениками, порядочными семьянинами и придерживающимися моральных и этических норм членами общества. Посредством православия, мыслит С.А. Рачинский, достигается «та высота, та безусловность нравственного идеала, которая делает русский народ народом христи- анским по преимуществу» [6, с. 123].

С.А. Рачинский был прекрасно осведомлён о содержании учебных книг К.Д. Ушинского, в своих "Заметках о сельской школе" он сообщал, что в книге "Родное слово" имеются "упражнения чересчур ребячливы для наших сельских учеников", а для чтения "в сельской школе крайне неудобны по своему содержанию" [4, с. 89]. К.Д. Ушинский сам соглашался с указанным Рачинским недостатком книги, отмечая это в одном из писем 1870 года: "Написать книгу для народной школы составляет уже давно мою любимую мечту, но, кажется, ей и суждено остаться мечтой. Прежде мне необходимо кончить "Антропологию" и потом только я сколько-нибудь применю "Родное слово" к потребностям сельской школы. И всего досаднее, что в голове это давно готово, так что тричетыре месяца прежнего здоровья и я бы, кажется, все окончил". Но, по воле судьбы, в том же году он умер и, соответственно, "Родное слово" как по мнению Рачинского, так и Ушинского, так и осталось "неприемлемым к потребностям сельской школы", хотя "книга замечательная, единственная в своем роде в нашей литературе... Пользуется она в нашем официально педагогическом мире авторитетом почти каноническим" [4, с. 52].

Педагог и меценат, он замечал, что не по достоинству второстепенное место "отведено преподаванию Закона Божия в средних учебных заведениях". Он - заботился о строительстве сельских школ, и все свои деньги направлял на это дело. Сельская школа преображается «...из учебного заведения в воспитательное... Школа захватывает всё существо ребёнка и становится великой силой, налагающей на него неизгладимый след. Какой? Это зависит от духа школы, от её организации, от персоналий, ею управляющих... Счастлива та школа, в которой имеется лампа, освещающая длинные зимние вечера, в которых ребята не вынуждены с трех часов по полудни сидеть в потемках или читать при свете догорающей печки. Но непроста задача учителя, который берёт на себя ответственность выполнять свои обязанности до конца, дополнять свои дневные уроки вечерними занятиями, без которых теряется смысл жизни несчастных школьников, оторванных от семьи, получающих учение лишь в течение двух, трёх зим, от Покрова до Светлого праздника... Да сохранит её Бог при первых неверных шагах её тяжёлого существования» [4, с. 13-15].

По Рачинскому: "Ни одним учителем не завершаются учебные силы школы. Рядом с ним в любой школе, заслуживающей название нормальной, действует законоучитель-священник... Благо той школе, в которой есть такой законоучитель! Она не умрёт, какие бы её не постигли внешние и внутренние трудности. Она пустит и глубокие корни, и широкие ветви... Но ещё важнее воспитательное воздействие священника на школу. Урок Закона Божия, сей любимый урок всех учеников, исходя из уст 
любимого священника, обучающего своей собственной жизнью, имеет громадную силу... Священник, и вне классов смотрящий за жизнью учеников, оторванный от семьи, посещающий их бедное жилище во время утренней и вечерней молитвы, входящий в их маленькие горести, в их тяжёлые нужды, делает больше и значительнее, чем самый искусный преподаватель. Он являет смысл этой насильственной жизни детей вдали от родимого дома, под защитой Церкви. Он завязывает со своей паствой те крепкие связи, которые одни лишь и привносят прочность и настоящую силу его школьным поучениям. Хороший священник - душа школы; школа - якорь спасения для священника. Всё это не предположения, не добрые пожелания, а краткая отповедь моих собственных наблюдений" [4, с. 33-34]. И далее: "Над живой Церковью никакое правительство в мире не властно... Наша сельская школа, сделавшись приходской, тем самым приобретает характер церковной..."

С.А. Рачинский замечал, что изучение Закона Божия в классе будет неминуемо вести к практическому участию подростков в богослужении в роли чтецов и певцов, а церковно-славянский язык открывать доступ к духовным сокровищам: к Библии и богослужебным книгам. С.А. Рачинский также писал: "Наряду с чтением Евангелия необходимо в школе и чтение Псалтыри, вопреки всяким дидактическим соображениям, которые можно привести против ее чтения". Несмотря на это, по его мнению, это «уникальная Книга», в которой содержатся высокие и вечные истины.

Сергей Александрович своей практической деятельностью и её осмыслением непрестанно актуализировал значимость труда духовенства и учительства в процессе воспитания и обучения: «Лишь в дружном сотрудничестве законоучителя и учителя возможен успех в преподавании Закона Божия, возможен правильный ход всего школьного дела" [4, с. 65].

Сопоставляя народное искусство и сельскую школу, Рачинский писал о приоритете школы, взращивающей нравственность, отражающуюся на социальном поведении: "Русский народ - народ глубоко верующий, и первая из его практических потребностей, наряду с удовлетворением нужд телесных, есть общение с Богом... Не театр ему нужен, а церковь, достойная своего высокого назначения, и школа, раскрывающая перед ним сокровища Церкви...; и если... соперником Церкви будет кабак, если пьяный разгул слишком часто заглушает в нем всякое движение духа, если в этой борьбе не произойдет скорый решительный поворот, то вечный позор всем нам, людям досуга и достатка, мысли и знания, печатного слова и правительственной власти! Позор и проклятие нашему мертвому образованию, нашей праздной болтовне, нашей духовной пустоте и бессилию!" [4, с. 81]. Главные сферы духовной жизни, по Рачинскому, - рели- гия, искусство и нравственное совершенствование человека [1, с. 21].

С.А. Рачинский был очень религиозным педагогом, прекрасно разбиравшимся в тонкостях православного учения написавшим некоторые богословские сочинения: "Божественная воля как источник существующего движения во Вселенной", "Религиозные воззрения А.С. Хомякова", под влиянием которого он принимает философскую концепцию апологии православия, выступающего ядром русской культуры, предсказание особого исторического предназначения и судьбы России.

Два года С.А. Рачинский путешествовал по странам Европы, где изучал вопросы народного образования и ботанику. Особо знакомился с педагогическими воззрениями И.Г. Песталоцци, придя к выводу, что наступило время возрождения педагогики, и что нужно проводить смелые опыты в воспитании человека. Вслед за К.Д. Ушинским, педагог считал, что стремления и идеалы любого общества нигде не выражаются так ярко, как в отношении к воспитанию.

Внушительную долю учебного времени народный учитель занимался изучением Закона Божия и церковно-славянского языка. Преподаванием Закона Божия занимался священник, в качестве метода выступали духовные беседы. Он был согласен с идеями К.Д. Ушинского, который докладывал: "Истинная, добросовестная наука, каковы бы даже не были личные верования самого ученого, не только найдет возможность настроить народное образование на прочной основе нашей народной религии, но, как величайшим сокровищем, как неисчерпаемым и уже существующим источником нравственного и умственного развития, будет дорожить этой исторической основой, столько же христианской, человеческой и художественной, сколько и народной" [8, с. 213].

С.А. Рачинский прекрасно понимал отличие идеалов русского и французского ребёнка. Для француза жизненным идеалом был честный труд и скромный заработок. Русский крестьянский подросток желал получить кусочек земли, передать его бедным, а потом уйти в монастырь. Это, как раз-таки влияние православной педагогики, ведущая в школах Рачинского к жизни во Христе и для Бога. Идеалом и общественной добродетелью у русских было благочестие [4, с. 23].

Идеал монашества традиционно признавался и превозносился в русском народе даже в самые нелёгкие времена. С.А. Рачинский упоминал и об этом: "Наша бедная сельская школа... Христианская потому, что учащиеся ищут в ней Христа... Во всех насажден живой зародыш благочестия... и смутный, но твердый религиозный и нравственный идеал: монастырь, жизнь в Боге и для Бога, отвержение себя - вот что совершенно искренно 
представляется конечной целью существования, недосягаемым блаженством этим веселым, практическим мальчишкам... Монастыря они не видели. Они разумеют тот таинственный, идеальный. Неземной монастырь, который рисуется перед ними в рассказах странников, в житиях святых, в собственных алканиях их души" [4, с. 26].

После семи лет преподавания в сельской школе-интернате С.А. Рачинский сделал вывод о том, что родители из крестьян приводят своих детей к нему в школу не из-за того, чтобы обучать их грамоте и счёту, а в основном по убеждению крестьян, что только школа способна укрепить и расширить в подростках базовые христианские принципы, включающие теплоту и сердечность в отношениях, нравственность, бескорыстие, честность, взаимопомощь, дисциплину и патриотизм, любовь к Отечеству.

Школа Рачинского в Татеве функционировала по своему выстроенному распорядку. Учебный процесс в ней продолжался круглый год. Обучение имело под собой строго христианские принципы. Установления церкви, такие как пост, строго соблюдались. Начало занятий ознаменовывалось молитвой, после чего дети расходились по учебным классам.

С.А. Рачинский был убеждён, что именно в условиях церковно-приходской школы возможно выстроить единой связи обучения с воспитанием. Церковно-приходская сельская школа - учреждение, в котором учится большинство населения России, предназначена стать отечественной национальной школой, воспитывающей человека интеллектуально и нравственно. «Чтобы стать на высоту этих задач, - писал С.А. Рачинский, - ей предстоит выработать особый тип учебный и нравственный, которому нет образца в школах западно-европейских». Школьный вопрос, с точки зрения Рачинского, это вопрос о духовных и традиционных основах и устоях нравственного воспитания, культуры, вопрос выбора и един- ства $[6$, с. 78-79].

С.А. Рачинский, как и К.П. Победоносцев прививали уважение к народным традициям, русской культуре, которые, в сущности, имеют духовные православные корни. «Ни в коем случае нельзя, - писал С.А. Рачинский, порывать связь с прошлым, которое есть основа национальной памяти, позволяющая нам плодотворно работать для будущего» [5, с. 31].

По мнению дореволюционного исследователя педагогической работы С.А. Рачинского, татевскией учитель церковно-приходской школы видел своей целью «стремление развить в детях религиозно-нравственное чувство и всей школе сообщить характер трудовой и честной семьи» [3, с. 22].

Таким образом, делается вывод, что рассмотренный нами просветитель народной школы видел в церкви не какой-то вспомогательный институт образовательного учреждения. С его точки зрения, церковь должна быть образцом и самоотверженным ресурсом для школы в отношении благочинной организации, использовании средств нравственного воспитания, построении отношений в соответствии с христианскими принципами, руководстве нравственным христианским идеалом. Церкви, принимая непосредственное участие в школьном деле, необходимо выполнять своё учительское призвание, а священнику помимо просто учительской функции следует осуществлять и духовную пастырскую заботу. С.А. Рачинский продолжал христианскую духовную традицию представления человека. Важнейшая цель воспитания - это не просто верующий человек, а полноценная личность, в которой вера и разум мирно сосуществуют. Много раз он заострял внимание на деятельном, творческом интересе в педагогической работе личности учителя, а педагогическое дело (как светского педагога, так и духовного лица) понималось как высшая богоподобная форма творчества.

\section{ЛИТЕРАТУРА}

1. Горбов, Н.М. С.А. Рачинский / Н.М. Горбов. - СПб., 1903.

2. Каптерев П.Ф. История русской педагогики / П.Ф. Каптерев. СПб., 1915.

3. Очерки по истории педагогики. Вып.3 / под ред. А.И. Анастасиева. - Казань, 1903.

4. Рачинский С.А. Сельская школа / С.А. Рачинский. СПб., 1902.

5. Рачинский, С.А. Absit omen / С.А. Рачинский. - М., 1901.

6. Рачинский, С.А. Сельская школа / С.А. Рачинский. - М., 1891.

7. Стеклов, М.Е. Школьный апостол / М.Е. Стеклов // Педагогика. - 1988. - №2.

8. Ушинский К.Д. Педагогические сочинения: в 6-ти т. / К.Д. Ушинский. М.: Педагогика, 1988. Т.2.

() Майстренко Алексей Игоревич (aleksei.maistrenko@mail.ru). 